Research Article

\title{
Abyssinone V-4' Methyl Ether, a Flavanone Isolated from Erythrina droogmansiana, Exhibits Cytotoxic Effects on Human Breast Cancer Cells by Induction of Apoptosis and Suppression of Invasion
}

\author{
Stéphane Zingue $\mathbb{C}^{1},{ }^{1,2,3}$ Abel Joël Gbaweng Yaya, ${ }^{4}$ Julia Cisilotto, ${ }^{2}$ \\ Larissa Vanelle Kenmogne, ${ }^{5}$ Emmanuel Talla, ${ }^{4}$ Anupam Bishayee $\mathbb{D}^{6},{ }^{6}$ \\ Dieudonne Njamen $\mathbb{D}^{3,},{ }^{3,5}$ Tânia Beatriz Creczynski-Pasa, ${ }^{2}$ and Derek Tantoh Ndinteh ${ }^{3}{ }^{3}$ \\ ${ }^{1}$ Department of Life and Earth Sciences, Higher Teachers' Training College, University of Maroua, P.O. Box 55, \\ Maroua, Cameroon \\ ${ }^{2}$ Department of Pharmaceutical Sciences, Health Sciences Centre, Federal University of Santa Catarina, Florianópolis, \\ Santa Catarina, Brazil \\ ${ }^{3}$ Department of Chemical Sciences, Faculty of Science, University of Johannesburg, Doornfontein 2028, South Africa \\ ${ }^{4}$ Department of Chemistry, Faculty of Science, University of Ngaoundere, P.O. Box 454, Ngaoundere, Cameroon \\ ${ }^{5}$ Department of Animal Biology and Physiology, Faculty of Science, University of Yaoundé 1, P.O. Box 812, Yaoundé, Cameroon \\ ${ }^{6}$ Lake Erie College of Osteopathic Medicine, Bradenton, FL 34211, USA
}

Correspondence should be addressed to Stéphane Zingue; stephanezingue@gmail.com and Derek Tantoh Ndinteh; dndinteh@uj.ac.za

Received 8 February 2020; Accepted 22 June 2020; Published 23 July 2020

Academic Editor: Susana Gorzalczany

Copyright ( $) 2020$ Stéphane Zingue et al. This is an open access article distributed under the Creative Commons Attribution License, which permits unrestricted use, distribution, and reproduction in any medium, provided the original work is properly cited.

\begin{abstract}
Abyssinone V-4' methyl ether (AVME) isolated from Erythrina droogmansiana was recently reported to exhibit anti-mammary tumor effect in mice. The present work was therefore aimed at elucidating its cellular and molecular mechanisms. To achieve our goal, the cytotoxicity of AVME against tumoral and non-tumoral cell lines was evaluated by resazurin reduction test; flow cytometry allowed us to evaluate the cell cycle and mechanisms of cell death; the mitochondrial transmembrane potential, reactive oxygen species (ROS) levels, and caspase activities as well as apoptosis-regulatory proteins (Bcl-2 and Bcl-XL) were measured in MDA-MB-231 cells. Further, the antimetastatic potential of AVME was evaluated by invasion assay. AVME exhibited cytotoxic effects in all tested tumor cell lines and induced a significant increase in the percentage of MDA-MB-231 cells at G2/M and S phases of the cell cycle in a concentration-dependent manner. AVME also induced apoptosis in MDA-MB-231 cells, which was accompanied by the activation of caspase- 3 and caspase- 9 and downregulation of Bcl-2 and Bcl-XL proteins. Moreover, AVME suppressed cancer cell invasion by the inhibition of the metalloproteinase- 9 activity. Findings from this study suggest that AVME has anti-breast cancer activities expressed through mitochondrial proapoptotic pathway including impairment of aggressive behaviors of breast cancer cells.
\end{abstract}

\section{Introduction}

The most common cancer in women is breast cancer which represents $29 \%$ of all diagnosed cancers in women [1]. Global estimates indicate that one million women are diagnosed with breast cancer each year and more than 400,000 of them die of this disease [2]. In Cameroon, 2,625 new cases of breast cancer are diagnosed in women each year $[3,4]$. Despite considerable advancement in medical care, deaths resulting from breast cancer are still on the increase 
[5]. This is particularly the situation in developing countries where governments are less ready to face this threat as a result of scarcity of diagnostic tools and the high cost of treatments [6]. Nevertheless, in first world countries, the problem of resistance and high cytotoxicity of many conventional drugs is one of the greatest difficulties that anticancer therapies are facing [7]. Therefore, majority of cancer patients usually incorporate natural therapy into conventional treatment protocols [8]. However, due to the lack of scientific evidence, the benefit of such substances is yet to be established. This is particularly true of phytoestrogens which are plant metabolites with a chemical structure of $17 \beta$-estradiol, which mimic estrogenic actions in mammals [9]. Since phytoestrogens possess both estrogenic and antiestrogenic activities, it is proposed that they could prevent estrogen-dependent malignancies such as breast, ovarian, uterine, and prostate cancers [10].

Erythrina (Fabaceae) contains more than 100 species distributed in the tropics and subtropics of America, Africa, and Australasia [11]. Extracts from Erythrina spp. exhibit a wide range of pharmacological properties, including cytotoxic $[12,13]$ and phytoestrogenic activities [14-17]. Among the most abundant metabolites isolated from this genus are abyssinones, which are prenylated flavanones that possess aromatase-inhibitory (abyssinone II), antioxidant and cytotoxic (abyssinone I and II), and anti-inflammatory (abyssinone V-4' methyl ether) activities [18-21]. Abyssinone V-4' methyl ether (AVME, Table 1) also possesses estrogenic and antiestrogenic effects [15, 22]. Recently, Tueche et al. [23] reported the cytotoxic effect of AVME isolated from Erythrina droogmansiana on four tumoral cell lines [including estrogen receptor-positive breast adenocarcinoma (MCF-7)] and its ability to prevent breast tumors induced by 7,12-dimethylbenz(a)anthracene (DMBA) in mice. Given its aforementioned antiestrogenic and cytotoxic effects, AVME might be a good candidate for the treatment of estrogen-dependent cancers, mainly breast cancer. As the information available on the cellular and molecular mechanisms of AVME on cancer cells is limited, this study aimed to better understand the underlying mechanisms of the anticancer activity of AVME. To achieve our goal, cell death (apoptosis or necrosis), cell cycle, mitochondrial transmembrane potential, ROS formation, caspase activities, apoptotic regulating proteins ( $\mathrm{Bcl}-2$ and $\mathrm{Bcl}-\mathrm{XL})$, invasion and expression of its regulators, matrix metalloproteinase- 2 (MMP-2), and MMP-9 were examined in MDA-MB-231 breast cancer cells.

\section{Materials and Methods}

2.1. Chemicals and Reagents. The following reagents were obtained from Sigma-Aldrich (St. Louis, MO, USA): acridine orange, trypan blue, resazurin, ethidium bromide, and cell culture mediums. Fetal bovine serum (FBS) and antibiotics were obtained from GIBCO (Grand Island, NY, USA). ApopNexin ${ }^{\text {TM }}$ FITC Apoptosis Detection Kit was obtained from Millipore (Billerica, MA, USA). 2-[4-(2Hydroxyethyl)piperazin-1-yl]ethanesulfonic acid (HEPES) was obtained from Ludwig Biotecnologia Ltda. (Alvorada,
RS, Brazil). Millicell ${ }^{\circledR}$ cell culture inserts $(8.0 \mu \mathrm{m})$ were obtained from Merck Millipore LTD (Tullagreen, Carrigtwohill, Ireland). JC-1 (5,5', $6^{\prime}, 6$-Tetrachloro-1,1', 3,3' -tetraethylbenzymidazolcarbocianyne iodide) and DCFH-DA were obtained from Invitrogen (Carlsbad, CA, USA). The antibodies Bcl-2 (monoclonal, C2; sc-7382), Bcl-XL (monoclonal, H5; sc-8392), and $\beta$-actin (monoclonal, C4; sc47778) were obtained from Santa Cruz Biotechnology, Inc. (Santa Cruz, CA, USA). All solutions were prepared using ultrapure water.

2.2. Collection and Authentication of Plant Material. Erythrina droogmansiana T. Durand (Fabaceae) root bark was harvested from Nkomekoui, Yaoundé, Centre Region of Cameroon, on August 21, 2010 ( 8:00 a.m.). It was identified by Mr. Victor Nana, a botanist in the Cameroon National Herbarium where a voucher specimen (no. 4261/SRFK) was preserved.

2.3. Extract Preparation. The root bark of E. droogmansiana was air-dried and macerated to produce a powder. Then, $1.2 \mathrm{~kg}$ of the powdered material was added with $5 \mathrm{~L}$ of ethyl acetate and incubated for $48 \mathrm{~h}$ at room temperature for extraction purposes. The mixture was filtered through Whatman filter paper no. 4. Ethyl acetate was recovered using a rotary evaporator, and $150 \mathrm{~g}$ $(12.5 \%)$ of crude extract was obtained.

2.4. Isolation of AVME. The isolation of AVME has been previously reported by Tueche et al. [23]. Briefly, $100 \mathrm{~g}$ of the ethyl acetate extract was subjected to column chromatography over silica gel packed in n-hexane. Gradient elution was carried out in increasing polarity using $n$-hexane, ethyl acetate, and methanol to obtain seven series of fractions that were mixed based on their respective thin layer chromatographic (TLC) profiles. Column elution with the solvent system hexane-EtOAc (90:10) yielded YG4 and other compounds. Chemical structures were elucidated by spectral methods (MS, NMR, and element analysis). Compound $\mathrm{YG}_{4}$ was a white powder $(500 \mathrm{mg})$, with an $[\mathrm{M}]^{+}$at $\mathrm{m} / z 422.2094$ corresponding to the molecular formula $\mathrm{C}_{26} \mathrm{H}_{30} \mathrm{O}_{5}$. This compound was identified as AVME (Table 1). The presence of a flavanone skeleton was evident from the ${ }^{1}$ HNMR spectra at $\delta 5.27(1 \mathrm{H}, \mathrm{br})$ and $2.68(1 \mathrm{H}, \mathrm{dd}, J=2.8$, and $17.2 \mathrm{~Hz})$ and at $\delta 3.06(1 \mathrm{H}, \mathrm{dd}, J=13.2$ and 17.2$)$, corresponding to $\mathrm{H}-2$ and $\mathrm{H}-3$ protons of the $\mathrm{C}$-ring of the flavanones, respectively. From the ${ }^{13} \mathrm{CNMR}$ spectra, the presence of a signal at 79.3 and 42.5 indicated the C-2 and C-3 of the C-ring of flavanones, respectively. The ${ }^{1} \mathrm{H}$ and ${ }^{13} \mathrm{CNMR}$ spectra data of AVME were compared with spectra already shown elsewhere [24].

2.5. Culture of Cell Lines. The following cell lines were acquired from the Rio de Janeiro Cell Bank (Federal University of Rio de Janeiro, Rio de Janeiro, Brazil): MCF-7 [human estrogen receptor- (ER-) positive breast carcinoma cells], MDA-MB-231 (human ER-negative breast carcinoma cells), 4T1 (mouse mammary tumor cells), SK-MEL-28 (human 
TABle 1: Abyssinone V-4' methyl ether (AVME) isolated from Erythrina droogmansiana.

\begin{tabular}{lcc}
\hline Chemical names & $\begin{array}{c}\text { Crystal } \\
\text { color }\end{array}$ & $\begin{array}{c}\text { Structure, molecular weight, and } \\
\text { formula }\end{array}$ \\
\hline
\end{tabular}

Abyssinone V-4' methyl ether, 4H-1-benzopyran-4-one, 2,3-dihydro-5,7dihydroxy-2-[4-methoxy-3,5-bis(3-methyl-s2-buten-1-yl)phenyl]

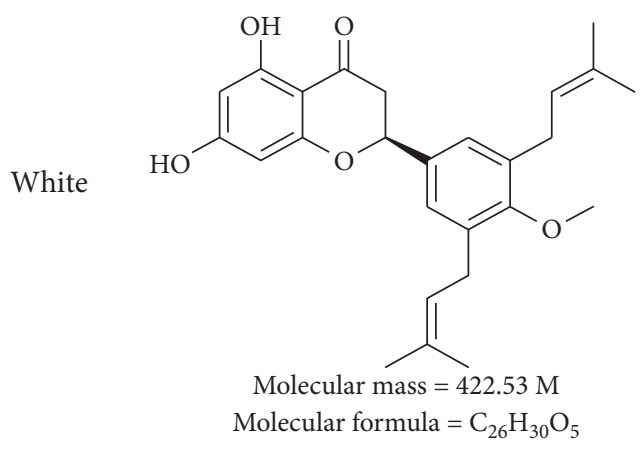

This compound was reported by Tueche et al. [23].

melanoma cells), SF-295 (human glioblastoma cells), HUVEC (human umbilical vein endothelium cells), MCR-5 (human fetal lung fibroblast cells), and NIH/3T3 (murine fibroblast cells).

MDA-MB-231, MCR-5, and SK-MEL-28 cell lines were cultured in Dulbecco's modified Eagle's medium (DMEM) containing 10\% FBS. RPMI 1640 medium with 10\% FBS was used for the growth and subculture of MCF-7, 4T1, HUVEC, NIH/3T3, and SF-295 cells. Each culture medium was supplemented with $100 \mathrm{U} / \mathrm{mL}$ penicillin, $100 \mu \mathrm{g} / \mathrm{mL}$ streptomycin, and $10 \mathrm{mM}$ HEPES. All cells were maintained at $37^{\circ} \mathrm{C}$ in a $5 \% \mathrm{CO}_{2}$ humidified atmosphere and $\mathrm{pH}$ 7.4. Every two days, cells were passaged. The number of viable cells was estimated at the beginning of each experiment by trypan blue method using a Neubauer chamber.

2.6. Resazurin Reduction Assay. The cytotoxic effect of AVME was investigated by Alamar Blue (resazurin salt) assay following the method of O'Brien et al. [25]. Briefly, $1 \times 10^{4}$ cells in culture medium were seeded in each well onto a 96-well plate overnight. AVME (5 to $100 \mu \mathrm{M}$ ) was then added to the seeded cells on subconfluent cell culture and incubated for $24 \mathrm{~h}$. Fluorescent intensity was captured using Perkin Elmer LS55 spectrofluorimeter (Becton Dickinson, San Jose, CA, USA) with excitation/emission wavelengths of $530 / 590 \mathrm{~nm}$. The $\mathrm{CC}_{50}$ (cytotoxic concentration that kills $50 \%$ of the cells) was calculated by nonlinear regression analysis of the logarithm of concentration with respect to the normalized response using SigmaPlot 11.0 software. Each experiment was done in triplicate and repeated thrice. The results were expressed as a percentage of cell viability. The effect of AVME in tumoral and nontumoral cells was compared using the selective cytotoxicity index (SCI), which was determined as described by Robles-Escajeda et al. [26] using the following formula: $\mathrm{SCI}=\mathrm{CC}_{50}$ of nontumoral cells/CC $\mathrm{C}_{50}$ of tumoral cells. For this calculation, the HUVEC cells were used as a representative of nontumoral cells.
2.7. Morphological Identification for Cell Death. Qualitative characterization of cell death mechanism was done using ethidium bromide (EB, 3,8-diamino-5-ethyl-6phenylphenanthridinium bromide) and acridine orange (AO, 3,6-dimethylamino acridine) stains. Cells containing intact membranes fixed AO in their DNA and emitted green fluorescence, while cells with damaged membranes emitted red fluorescence. MDA-MB-231 cells were seeded onto 12well plates $\left(3.5 \times 10^{5}\right.$ cells $\left./ \mathrm{mL}\right)$ on subconfluent cell culture and incubated with AVME at 10 or $20 \mu \mathrm{M}$ or DMSO (solvent control) for $24 \mathrm{~h}$. After incubation, the medium was decanted and the cells were washed with phosphate-buffered saline (PBS). Subsequently, the mixed dye $(0.3 \mu \mathrm{g} / \mathrm{mL}$ of $\mathrm{AO}$ and $1 \mu \mathrm{g} / \mathrm{mL}$ of EB) was added to each well, and the cells were viewed immediately under a Nikon eclipse TS100 inverted microscope at 100 and $400 \times$ magnifications with excitation filter $480 / 30 \mathrm{~nm}$, dichromatic mirror cut-on $505 \mathrm{~nm} \mathrm{LP}$, and barrier filter 535/40 nm. Images were captured using a Nikon COOLPIX digital camera connected to a computer and analyzed by image editor software (Image $\left.{ }^{\circledR}\right)$.

2.8. Flow Cytometry for Detection of Apoptotic Cells. Annexin FITC-conjugated $(1: 500)$ and propidium iodide (PI) fluorochrome-labeled cells were used to determine the nature of cell death (apoptosis or necrosis). After platting MCF-7 and MDA-MB-231 cells $\left(3.5 \times 10^{5}\right.$ cells $\left./ \mathrm{mL}\right)$ in a $12-$ well plates, they were incubated with AVME at 10 and $20 \mu \mathrm{M}$ for MDA-MB-231 cells and 11 and $22 \mu \mathrm{M}$ for MCF-7, or solvent control (DMSO) for $24 \mathrm{~h}$. Cells were then washed twice with cold PBS and suspended again in a buffer containing $10 \mathrm{mM}$ HEPES (pH 7.4), $150 \mathrm{mM} \mathrm{NaCl}, 5 \mathrm{mM} \mathrm{KCl}$, $1 \mathrm{mM} \mathrm{MgCl}_{2}$, and $1.8 \mathrm{mM} \mathrm{CaCl}_{2}$. The pellets were stained on ice in the dark for $15 \mathrm{~min}$ with a fluorescent probe solution containing $50 \mathrm{mg} / \mathrm{mL}$ PI and $1 \mathrm{mg} / \mathrm{mL}$ Annexin. The total percentage of cells experiencing apoptosis was demarcated as the sum of both early and late facets of apoptosis (Annexin $\mathrm{V}$-FITC positive), lower and upper right quadrants in the 
two-parameter dot plots, as previously described by RoblesEscajeda et al. [26]. The WinMDI 2.9 software and the flow cytometer BD FACSVerse (Becton Dickinson, Franklin Lakes, NJ, USA) were used for analysis. Each experiment was repeated thrice.

2.9. Cell Cycle Analysis. MCF-7 and MDA-MB-231 cells were plated onto 12 -well plates $\left(3.5 \times 10^{5}\right.$ cells $\left./ \mathrm{mL}\right)$ and incubated for $24 \mathrm{~h}$. After replacing the medium, AVME was added at concentrations of 10 and $20 \mu \mathrm{M}$ (for MDA-MB231) or 11 and $22 \mu \mathrm{M}$ (for MCF-7) or solvent control (DMSO) and incubated for $24 \mathrm{~h}$. The cells were washed several times with cold PBS, resuspended in 70\% ethanol, and fixed at $-20^{\circ} \mathrm{C}$. A mixture of PBS and $2 \%$ bovine serum albumin (BSA) was added after $30 \mathrm{~min}$. Cell pellets obtained after centrifugation were washed, permeabilized with a lysis buffer $(0.1 \%$ Triton X-100 and $100 \mu \mathrm{g} / \mathrm{mL}$ RNase), and stained with PI $(20 \mu \mathrm{g} / \mathrm{mL})$. Cell cycle was assayed using a flow cytometry (BD FACSVerse, Becton Dickinson, Franklin Lakes, NJ, USA), and results were analyzed using WinMDI 2.9 software. Each experiment was repeated thrice.

\subsection{Analysis of Mitochondrial Membrane Potential ( $\Delta \Psi m)$.} The probe JC-1 (5,5',6'6-tetrachloro-1,1',3,3'-tetraethylbenzymidazolcarbocianine iodide), a lipophilic cationic fluorochrome, was used to measure the mitochondrial transmembrane potential of MDA-MB-231 cells. MDA-MB-231 cells were seeded onto 12 -well plates $\left(3.5 \times 10^{5}\right.$ cells $\left./ \mathrm{mL}\right)$ and incubated for $24 \mathrm{~h}$. Thereafter, AVME (at 10 and $20 \mu \mathrm{M}$ ), DMSO (solvent control), or uncoupler CCCP (positive control) was added to cells on subconfluent cell culture. After $6 \mathrm{~h}$ of incubation, JC-1 $(10 \mu \mathrm{g} / \mathrm{mL})$ was added and cells were further incubated for $30 \mathrm{~min}$ at $37^{\circ} \mathrm{C}$ in $5 \% \mathrm{CO}_{2}$. The cells were then washed twice with PBS and resuspended in PBS. A Perkin Elmer LS55 spectrofluorimeter (Becton Dickinson, San Jose, CA) was used to measure the fluorescence intensities. The excitation/emission wavelength for JC-1 was $488 / 525 \mathrm{~nm}$. The mitochondrial potential was calculated by the ratio of 590/ 525 fluorescence intensities and compared with the control cells with $100 \% \Delta \Psi \mathrm{m}$. Each experiment was performed thrice.

2.11. Measurement of ROS. 2',7'-Dichlorodihydrofluorescein diacetate (DCHF-DA) was used to evaluate the formation of intracellular free radicals. DCHF-DA is oxidized to dichlorofluorescein (DCF) in the presence of ROS. Briefly, MDA-MB-231 cells $\left(3.5 \times 10^{5}\right.$ cells $\left./ \mathrm{mL}\right)$ were seeded onto 12 -well plates and incubated for $24 \mathrm{~h}$. Thereafter, the medium was decanted, and AVME at 10 and $20 \mu \mathrm{M}$ or solvent control (DMSO) was added to the wells on subconfluent cell culture. After $12 \mathrm{~h}$ incubation, cells were treated with a medium containing $10 \mu \mathrm{M}$ DCHF-DA. The cells were then washed four times with cold PBS, detached by trypsinization, and centrifuged at $600 \times \mathrm{g}$ for $10 \mathrm{~min}$. PBS-EDTA was used to suspend cell pellets whose DCF fluorescence signal was detected using a spectrofluorimeter (Perkin Elmer LS55,
Becton Dickinson, San Jose, CA, USA) with excitation at $485 \mathrm{~nm}$ and emission at $535 \mathrm{~nm}$. Fluorescence units were expressed as the percentage of ROS and normalized by the total protein content measured by a modified method described by Lowry et al. [27].

2.12. Determination of Caspase Activities. Caspase-3, caspase-9, and caspase- 8 activities were measured after incubation of $2 \times 10^{6} \mathrm{MDA}-\mathrm{MB}-231$ cells for $8 \mathrm{~h}$ at $37^{\circ} \mathrm{C}$ with AVME at concentrations of 10 and $20 \mu \mathrm{M}$. Cells were washed twice with PBS and then subjected to lysis in a buffer prepared as follows: $1 \mu \mathrm{g} / \mathrm{mL}$ pepstatin $\mathrm{A}, 5 \mu \mathrm{g} / \mathrm{mL}$ aprotinin, $5 \mathrm{mM}$ 3-[(3-cholamidopropyl)-dimethylammonio]-1-propanesulfonate (CHAPS), $50 \mathrm{mM}$ HEPES ( $\mathrm{pH} 7.4$ ), $5 \mathrm{mM}$ dithiothreitol (DTT), $1 \mathrm{mM}$ phenylmethylsulfonyl fluoride (PMSF), and $1 \mu \mathrm{g} / \mathrm{mL}$ leupeptin at $8^{\circ} \mathrm{C}$ for $20 \mathrm{~min}$. An aliquot of AVME added to a buffer containing $20 \mathrm{mM}$ HEPES $(\mathrm{pH}$ 7.4), 0.1\% CHAPS, $2 \mathrm{mM}$ EDTA, $5 \mathrm{mM}$ DTT, and 5\% sucrose was added to the cells. The reaction medium was complemented with $50 \mu \mathrm{M}$ Ac-DEVD-AMC, $100 \mu \mathrm{M}$ AcLEHD-AFC, or $25 \mu \mathrm{M}$ of Ac-IETD-AMC, fluorogenic substrates for caspase-3, caspase-9, and caspase-8, respectively. The caspase activities were therefore determined spectrofluorimetrically by the production of 7-amino-4methyl coumarin (AMC) or 7-amino-4-trifluoromethylcoumarin (AFC) after $2 \mathrm{~h}$ incubation at $37^{\circ} \mathrm{C}$. The protein content was assayed as indicated earlier. The caspase activities were expressed as percentages based on the values of fluorescent units normalized with the protein concentration.

2.13. Western Blot Analysis. MDA-MB-231 cells were seeded in a density of $1 \times 10^{7}$ cells/well onto a 6 -well plate. After complete cell attachment within $24 \mathrm{~h}$, AVME was added at concentrations of 10 and $20 \mu \mathrm{M}$ on subconfluent cell culture and incubated for $24 \mathrm{~h}$. The cells were then broken in a lysis buffer, sonicated, and centrifuged for $10 \mathrm{~min}$ at $10,000 \times \mathrm{g}$ to extract the proteins. The protein content was determined as mentioned previously. Sodium dodecyl sulfate-polyacrylamide gel electrophoresis (SDSPAGE) using a $15 \%$ gel was performed by loading aliquots of $50 \mu \mathrm{g}$ of protein from each sample. The separated protein bands were transferred to nitrocellulose membranes which were blocked with 5\% BSA in Tris-buffered saline containing Tween 20 (TBS-T). The membranes were incubated overnight at $4^{\circ} \mathrm{C}$ with primary-human specific monoclonal antibodies for Bcl-2, Bcl-XL, or $\beta$-actin (at a $1: 1,000$ dilution) in TBS-T containing $2.5 \%$ BSA. Subsequently, the membranes were washed four times with TBS-T and incubated with the anti-mouse IgG-peroxidase conjugated secondary antibody ( $1: 10,000$ dilution). Immune complexes were observed by chemiluminescence using Amersham ECL ${ }^{\mathrm{TM}}$ (GE Healthcare, London, UK), Western blotting detection reagent, and ChemiDoc MP imaging system (Bio-Rad, St. Louis, MO, USA). Proteins were quantified using Bio-Rad image analysis software. In this experiment, $\beta$-actin served as internal control. 
2.14. Cell Invasion Assay. Matrigel precoated Millicell culture inserts $(8.0 \mu \mathrm{m}$ pores, $10 \mathrm{~mm}$ diameter $)$ contained in 24-well plates were used to assess chemotaxis. Before the experiment, inserts were washed twice with DMEM and rehydrated for $30 \mathrm{~min}$ in DMEM. An aliquot of Matrigel (1 : 10 in DMEM without serum) was added to the inserts. The insert with Matrigel was incubated at $37^{\circ} \mathrm{C}$ for $1 \mathrm{~h}$ to enable polymerization. A suspension of $5 \times 10^{4}$ MDA-MB-231 cells was homogenously added in the upper chamber whereas the lower chamber was filled with DMEM containing $10 \%$ FBS. Cells were incubated for $48 \mathrm{~h}$ in the presence of AVME (10 and $20 \mu \mathrm{M})$ or DMSO (control) to allow them to migrate. Afterward, the upper surface of the transwell membrane was wiped gently with a cotton swab to remove nonmigrating cells and fixed with $5 \%$ glutaraldehyde followed by staining with $0.1 \%$ crystal violet solution for $10 \mathrm{~min}$. Images were captured with a Nikon COOLPIX digital camera. A minimum of five fields per insert was counted by image editor software (Image ${ }^{\circledR}$ ). Each experiment was performed twice, and the average of cells/field was calculated. The number of untreated cells that invaded was considered to be $100 \%$, and the percentage of cells treated with AVME was calculated based on the number of cells in the control group.

\subsection{Determination of Metalloproteinase Activities. A} zymography assay was performed to determine the activity of MMP-2 and MMP-9 as reported by Cisilotto et al. [28]. Briefly, $3 \times 10^{5}$ cells/well were seeded, and, after incubation with AVME at 10 and $20 \mu \mathrm{M}$ for $24 \mathrm{~h}$ in serum-free medium, the culture medium containing the metalloproteinases released by the cells was removed. Samples were centrifuged at $8000 \times \mathrm{g}$ for $20 \mathrm{~min}$ at $4^{\circ} \mathrm{C}$ to remove dead cells and cell fragments. Total protein was measured by a modified method described by Lowry et al. [27]. The proteins $(30 \mu \mathrm{g})$ were separated by electrophoresis using $10 \%$ polyacrylamide gel with $0.5 \%$ of gelatin. Thereafter, gels were treated with $2.5 \%$ Triton X-100 with gentle agitation for $30 \mathrm{~min}$ at room temperature. Gels were further incubated in a buffer with $0.05 \mathrm{M}$ Tris- $\mathrm{HCl}, 10 \mathrm{mM} \mathrm{CaCl}_{2}$, and $1 \mu \mathrm{M} \mathrm{ZnCl} 2(\mathrm{pH} 8.0)$ overnight at $37^{\circ} \mathrm{C}$. Gels were stained with a Coomassie solution (0.5\% Coomassie Blue, 30\% methanol, and 10\% acetic acid) for $30 \mathrm{~min}$ and eventually destained with a solution containing 10\% methanol and 10\% acetic acid. Zymographic images were processed using ENDURO $^{\mathrm{TM}}$ GDS photodocumentation system (Labnet International, Edison, NJ, USA). Protein bands were quantified using the Image ${ }^{\circledR}$ software.

2.16. Statistical Analysis. Results are presented as mean$\mathrm{s} \pm$ standard deviation (SD) of triplicates from 3-6 independent experiments. Statistical analysis of data with Graphpad Prism software version 8.0 was performed using the one-way analysis of variance (ANOVA) followed by Dunnett's post hoc test for multiple comparisons. A $p$ value less than 0.05 was considered to be statistically significant.

\section{Results}

3.1. Cytotoxicity of $A V M E$. The cytotoxicity of AVME was tested in five tumoral (MCF-7, MDA-MB-231, 4T1, SKMEL-28, and SF-295) and three nontumoral cell lines (NIH3T3, HUVEC, and MRC-5) (Table 2). After $24 \mathrm{~h}$ of exposure, AVME registered a significant cytotoxicity on different tumoral cell lines with a maximum pronounced effect against $4 \mathrm{~T} 1 \quad\left(\mathrm{CC}_{50}=18 \pm 1.51 \mu \mathrm{M}\right)$ and SK-MEL-28 $\left(\mathrm{CC}_{50}=18 \pm 08 \mu \mathrm{M}\right)$ cells, followed by MDA-MB-231 $\left(\mathrm{CC}_{50}=20 \pm 1.12 \mu \mathrm{M}\right), \mathrm{MCF}-7\left(\mathrm{CC}_{50}=21 \pm 2.5 \mu \mathrm{M}\right)$, and SF$295\left(\mathrm{CC}_{50}=21 \pm 1.03 \mu \mathrm{M}\right)$ cells. Concerning nontumoral cell lines, except murine fibroblast cells (NIH-3T3) where the $\mathrm{CC}_{50}$ was also pronounced $(21 \pm 0.89 \mu \mathrm{M})$, the cytotoxicity was of lesser magnitude in other two nontumoral cell lines [HUVEC $\quad\left(\mathrm{CC}_{50}=27 \pm 1.27 \mu \mathrm{M}\right)$ and MRC-5 $\left.\left(\mathrm{CC}_{50}=30 \pm 4.28 \mu \mathrm{M}\right)\right]$. The selective cytotoxicity index (SCI) was around 1.3 showing greater selectivity of AVME to cancer cells.

3.2. Cell Death Induced by AVME. Figures 1(a) and 1(b) show MDA-MB-231 cells stained with AO and EB. Figure 1(b) illustrates condensed green nuclei (apoptotic cell), indicating chromatin condensation. Further, the cell death mechanisms induced by AVME were evaluated through flow cytometry.

As shown in dot plots (Figure 2(a) and Supplementary Figure 1(a)), the viable cells exhibited low FITC and propidium iodide (PI) fluorescence, whereas the cells in early apoptosis presented high FITC fluorescence but low PI fluorescence. The viable, apoptotic, and necrotic control cells were $96.26 \%, 1.88 \%$, and $1.86 \%$, respectively. The concentration-dependent increase in the percentage of apoptotic cells with the maximum of $12.83 \%$ at $20 \mu \mathrm{M}$ of AVME suggests that it induced apoptosis in MDA-MB-231 cells (Figure 2(b)) and 23.13\% (at $11 \mu \mathrm{M}$ ) and 53.24\% (at $21 \mu \mathrm{M}$ ) of apoptotic cells in MCF-7 cells (Supplementary Figures 1(a) and 1(b)).

3.3. Cell Cycle. The effects of AVME on cell cycle progression of MCF-7 and MDA-MB-231 cells were assessed by flow cytometric analysis. AVME significantly increased the percentage of cell population at G2/M and S phases in MDAMB-231 cells in a concentration-dependent manner (Figures 3(c) and 3(d)).

AVME did not induce significant change in MCF-7 cell cycle after $24 \mathrm{~h}$ of incubation at the concentrations of 5, 11, and $21 \mu \mathrm{M}$ (Supplementary Figure 2).

3.4. Mitochondrial Transmembrane Potential. Since AVME was capable of inducing apoptosis, we decided to examine whether it acts via reactive oxygen species- (ROS-) mediated mitochondrial dysfunction pathway. The JC-1 probe emits fluorescence peaks with strong (red) or low (green) mitochondrial membrane potentials. AVME significantly ( $p=0.009$ and $p=0.005)$ decreased mitochondrial transmembrane potential of MDA-MB-231 cells at the tested 
TABLE 2: Comparative $\mathrm{CC}_{50}$ and selective cytotoxicity index (SCI) values of AVME in tumoral and non-tumoral cell lines.

\begin{tabular}{|c|c|c|c|c|}
\hline \multicolumn{4}{|c|}{$\mathrm{CC}_{50}(\mu \mathrm{M})[$ mean $\pm \mathrm{SD}]$} & SCI \\
\hline Tumoral cell lir & & \multicolumn{2}{|c|}{ Non-tumoral cell lines } & $\mathrm{CC}_{50}$ HUVEC cells/CC $\mathrm{CC}_{50}$ tumoral cells \\
\hline MCF-7 & $21 \pm 3.51$ & HUVEC & $27 \pm 2.51$ & 1.3 \\
\hline MDA-MB-231 & $20 \pm 2.18$ & MRC-5 & $30 \pm 0.78$ & 1.4 \\
\hline $4 \mathrm{~T} 1$ & $18 \pm 1.11$ & $\mathrm{NIH}-3 \mathrm{~T} 3$ & $21 \pm 0.89$ & 1.5 \\
\hline SK-MEL-28 & $18 \pm 3.1$ & & & 1.5 \\
\hline SF-295 & $21 \pm 2.03$ & & & 1.3 \\
\hline
\end{tabular}

$\mathrm{CC}_{50}$ : concentration of AVME which results in $50 \%$ of cell viability. SCI: selective cytotoxicity index. The results are expressed as mean \pm SD of at least 3 independent experiments. The results are expressed as mean $\pm \mathrm{SD}$ of at least 3 independent experiments. Selectivity index: $\sim 1.3\left(\mathrm{CC}_{50}\right.$ nontumoral cells/ $\mathrm{CC}_{50}$ tumoral cells).
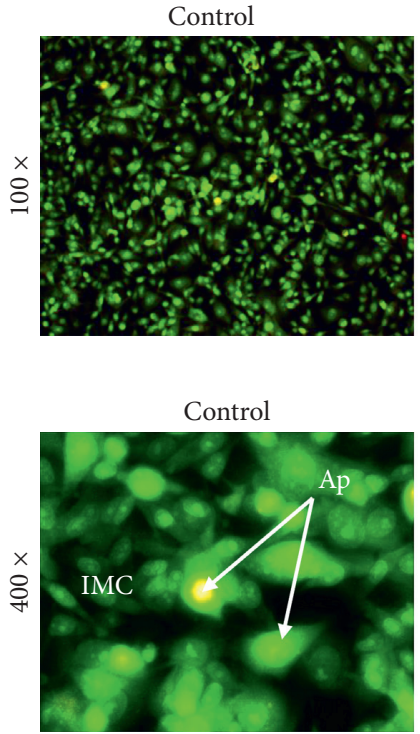

AVME $10 \mu \mathrm{M}$

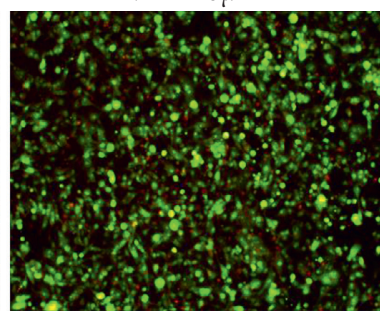

(a)

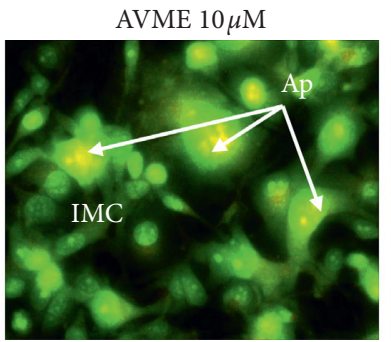

(b)

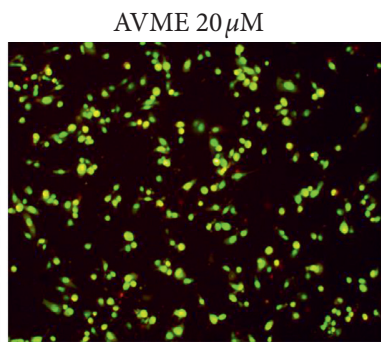

AVME $20 \mu \mathrm{M}$

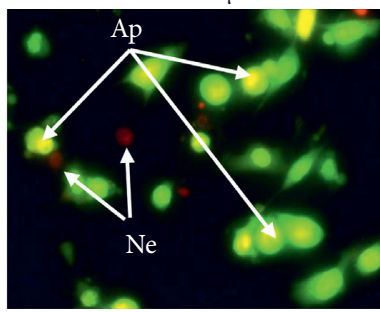

FIgURE 1: Effect of AVME on cell death in MDA-MB-231 cells (qualitative evaluation). Representative fluorescence microscopic images $100 \times$ (a) and $400 \times$ cells (b) double-stained with acridine orange and ethidium bromide. IMC: intact membrane cell, Ap: apoptotic cells, Ne: necrotic cells.

concentrations ( 10 and $20 \mu \mathrm{M})$, as evidenced by a decrease of red/green fluorescence ratio. Similar effects were achieved with $\quad 5,5^{\prime}, 6^{\prime}, 6$-tetrachloro-1, $1^{\prime}, 3,3^{\prime}$-tetraethylbenzymidazolcarbocianyne iodide (CCCP) $(10$ and $100 \mu \mathrm{M})$ used as positive control in this experiment (Figure 4(a)).

3.5. ROS Levels. Changes in intracellular ROS levels were detected using a fluorescence probe, $2^{\prime}, 7^{\prime}$-dichlorofluorescein diacetate (DCFH-DA). DCFH is normally produced via hydrolysis by intracellular esterases followed by its oxidation to DCF. The fluorescence intensity resembles the level of ROS. Significant increases in ROS levels in MDA-MB-231 cells were observed after incubation with AVME at concentrations of $10 \mu \mathrm{M}(p=0.047)$ and $20 \mu \mathrm{M}$ $(p=0.045)$, and similar effects were found in the positive control assay where the cells were exposed to $\mathrm{H}_{2} \mathrm{O}_{2}(4 \mathrm{mM})$ (Figure 4(b)).

3.6. Caspases Activity. In further investigation of how AVME activates apoptosis in MDA-MB-231 cells, the activities of caspase- $3,-8$, and -9 were determined. A significant increase in the activities of caspase-3 (50\%) and caspase- 9 (45\%) was observed after $8 \mathrm{~h}$ of cell incubation with AVME at the concentration of $20 \mu \mathrm{M}$, whereas it failed in caspase-8 activity (Figure 5).

3.7. Bcl-2 Family Protein Expression. Bcl-2 and Bcl-XL proteins are known to be overexpressed in various human cancers and act as suppressors of apoptosis, resulting in the survival of malignant cells. Western blot assay was used to quantify Bcl-2 and Bcl-XL proteins in MDA-MB-231 cells. As illustrated in Figure 6(a), AVME induced a reduction in $\mathrm{Bcl}-2$ and $\mathrm{Bcl}-\mathrm{XL}$ protein contents in MDA-MB-231 cells in a concentration-dependent manner.

3.8. Cell Invasion. A significant inhibition of invasion of MDA-MB-231 cells was demonstrated by AVME at $10 \mu \mathrm{M}$ $(p=0.0006)$ and $20 \mu \mathrm{M}(p=0.0002)$ in a concentrationdependent manner in comparison with control cells (Figure 7). A $40 \%$ reduction of cell invasion was achieved by the 

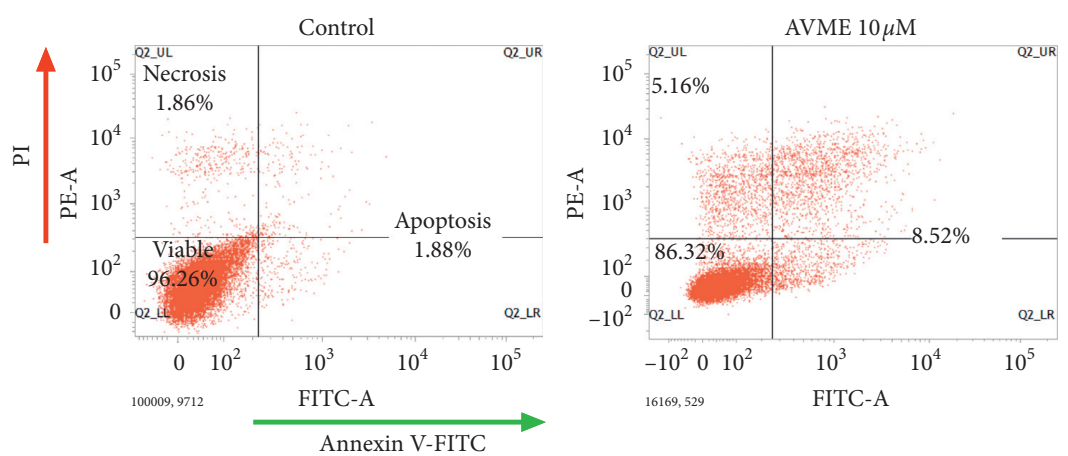

(a)

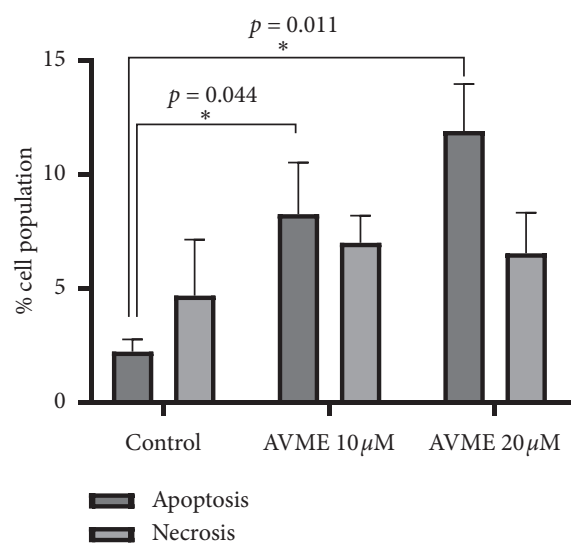

(b)

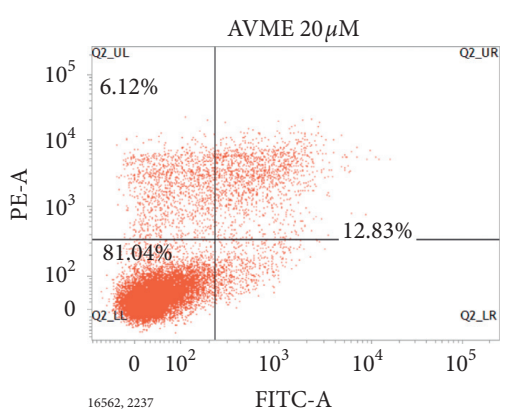

16562, 2237 $\quad$ FITC-A 


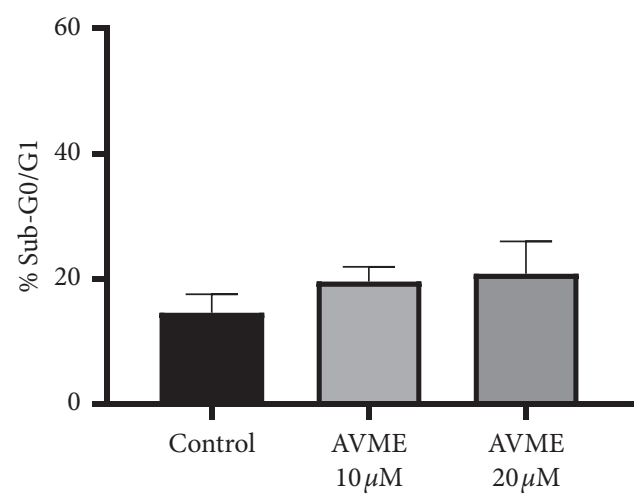

(a)

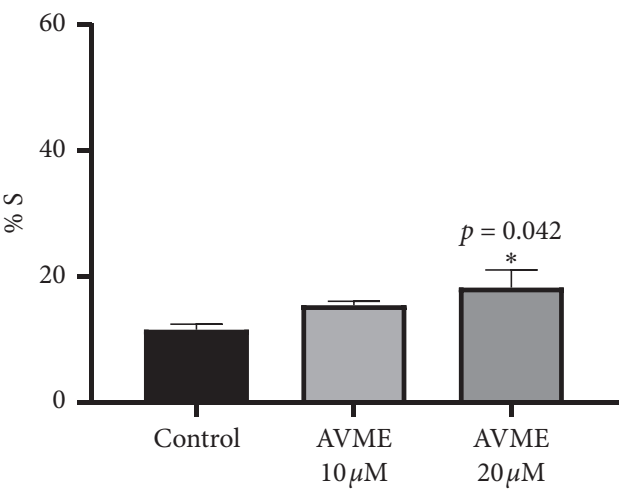

(c)

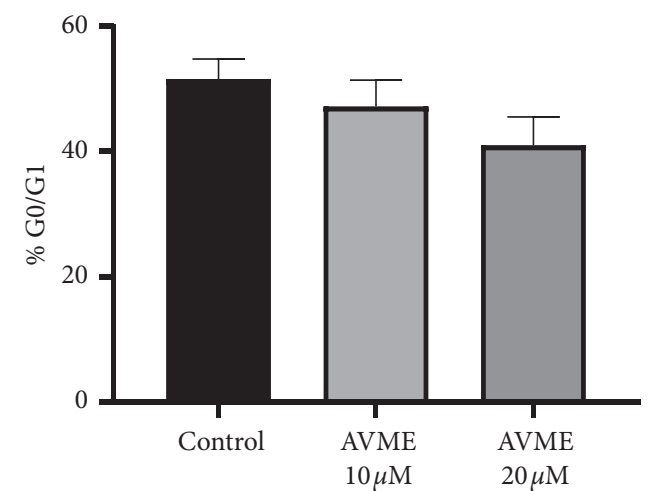

(b)

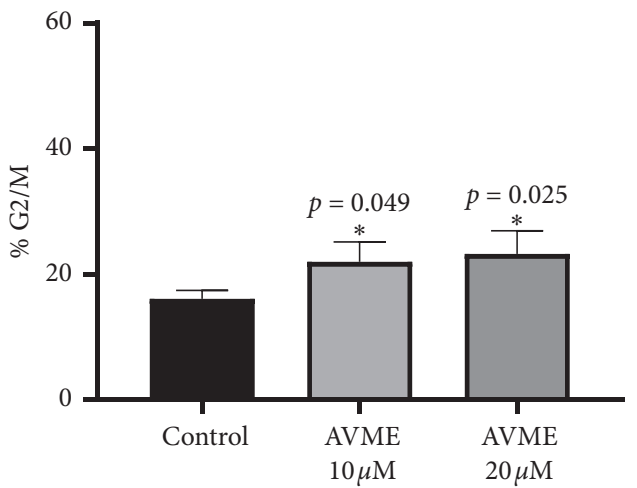

(d)
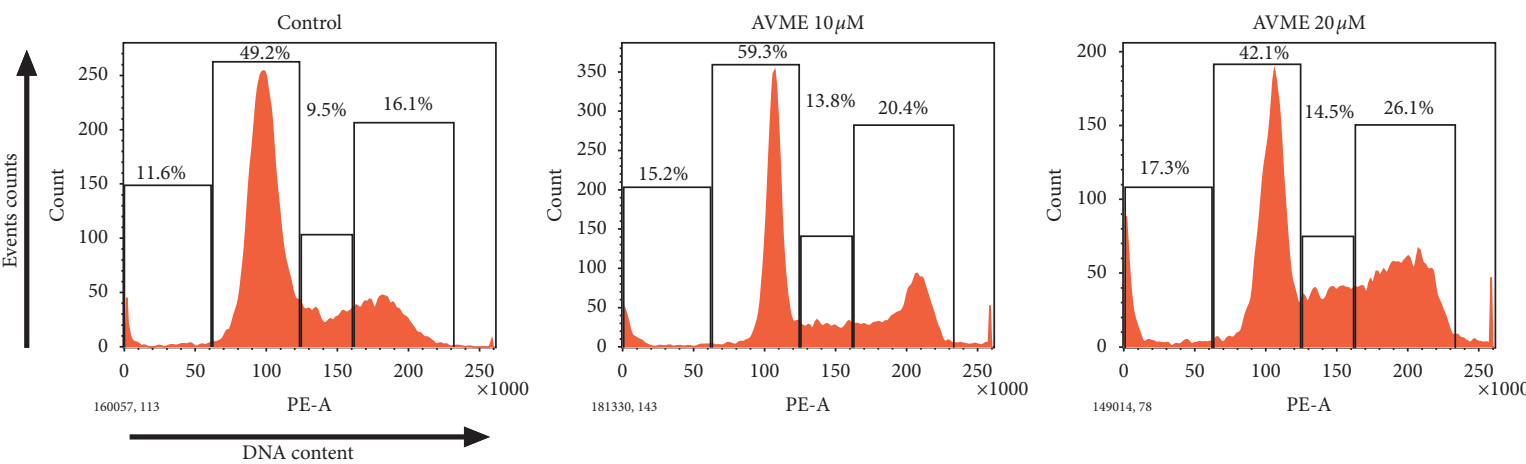

(e)

Figure 3: Effect of AVME on cell cycle distribution in MDA-MB-231 cells after $24 \mathrm{~h}$. Cells were treated with 10 and $20 \mu \mathrm{M}$ of AVME for $24 \mathrm{~h}$ and stained with PI. Following flow cytometry, cellular DNA profile was analyzed using the software WinMDI 2.9. (a-d) Results are expressed as the percentage of cell in each cell cycle phase of three independent experiments. ${ }^{*} p<0.05$. (e) Data representing the percentage of cell counts in each cell cycle phase are also shown.

indicating a weak selective activity for cancer cells. In spite of this fact, we believe it is worthwhile to elucidate the underlying mechanisms considering the limitations of current chemotherapeutic drugs regarding undesirable toxicity and resistance development. In this study, it was found that AVME induced apoptosis in MDA-MB-231 and MCF-7 cells (supplementary data). Apoptosis represents one of the targets of the search for alternative treatment against cancer [38]. Generally, apoptosis triggered by either extrinsic or intrinsic mechanisms is known to play a vital role in carcinogenesis and hence can be exploited to identify novel compounds for cancer therapy $[39,40]$.
Caspase- 3 and caspase- 9 enzymes, members of cysteine protease family, are indispensable for the breakup of the nuclear scaffold and cytoskeleton [41]. These enzymes play central roles in the process of apoptosis and act as initiators and executioners. The intrinsic mitochondrial pathway can be stimulated by irreparable genetic damage, considerable oxidative stress, and hypoxia, resulting in mitochondrial permeability followed by a release of cytochrome $c$ into the cytosol [42]. A balance between proapoptotic proteins (such as Bax, Bad, Bak, and Bcl-Xs) and antiapoptotic proteins (like Bcl-2, Bcl-XL, and Mcl-1) regulates the cytochrome $c$ release [42]. The apoptosome complex made up of 


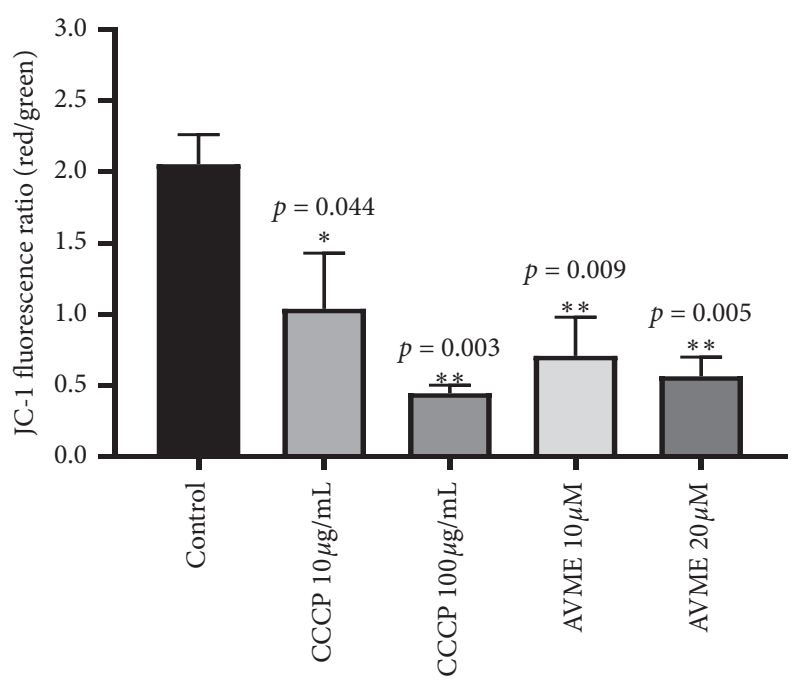

(a)

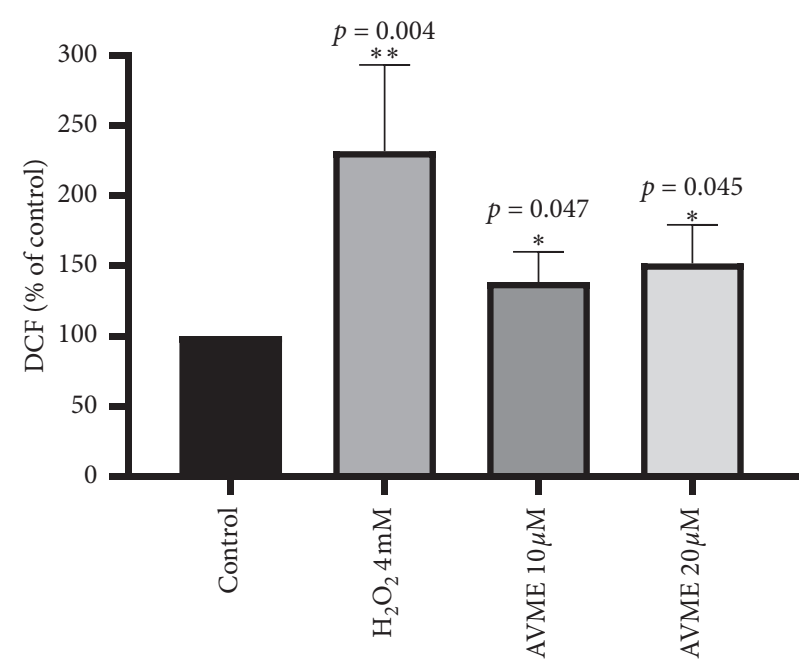

(b)

Figure 4: Effects of AVME on mitochondrial transmembrane potential (a) and intracellular ROS levels (b) in MDA-MB-231 cells treated with 10 and $20 \mu \mathrm{M}$ of AVME. The mitochondrial membrane potential was spectrophotometrically measured using the JC-1 fluorescent probe, while ROS level was determined using the DCHF-DA fluorescent probe. The uncoupler CCCP $\left(10\right.$ and $100 \mu \mathrm{g} / \mathrm{mL}^{2}$ and $\mathrm{H}_{2} \mathrm{O}_{2}(4 \mathrm{mM})$ were used as positive control for the mitochondrial transmembrane potential and the ROS determination, respectively. Results are expressed as mean \pm SD of three independent experiments. ${ }^{*} p<0.05$ and ${ }^{* *} p<0.01$ as compared to control.

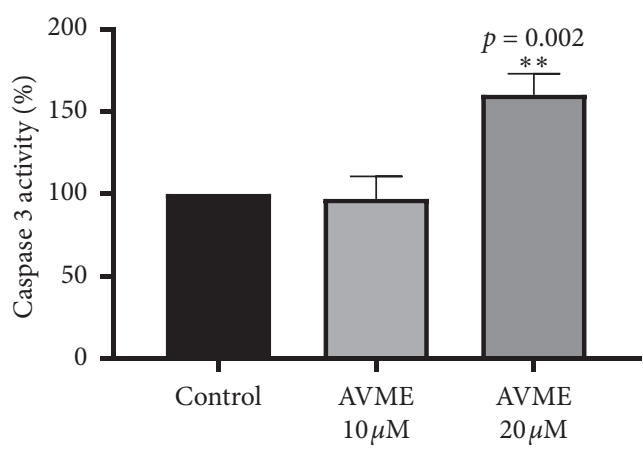

(a)

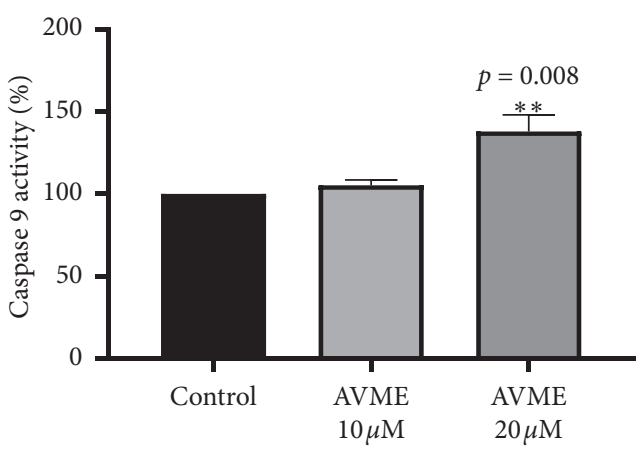

(b)

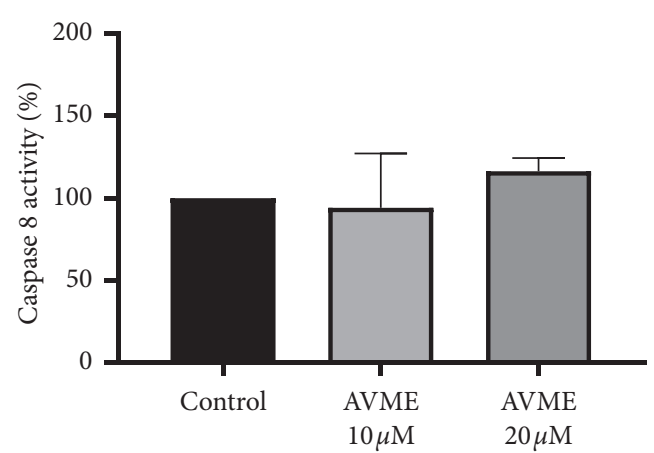

(c)

Figure 5: Activation of caspase-3 (a), caspase-9 (b), and caspase-8 (c) by AVME in MBA-MD-231 cells. Cells were incubated with 10 and $20 \mu \mathrm{M}$ AVME for $8 \mathrm{~h}$. Caspase activities were measured by monitoring the cleavage of fluorogenic substrates specific for each caspase. The activity is given as percentage. Results are expressed as the mean $\pm \mathrm{SD}$ of three independent experiments. ${ }^{* *} p<0.01$ as compared to control.

cytochrome $c$, caspase- 9 , and Apaf- 1 then activates caspase- 3 [43]. The increase in caspase- 3 and caspase- 9 activities following exposure to AVME indicates that this natural compound induces apoptosis by the intrinsic pathway. AVME failed to activate caspase- 8 , which is activated by a ligand bound to death receptors on the cell surface. The 


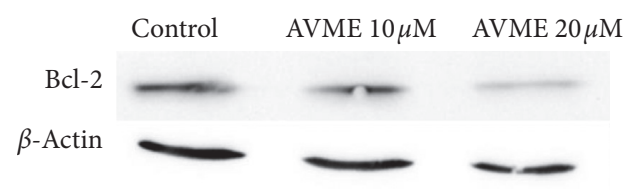

(a)

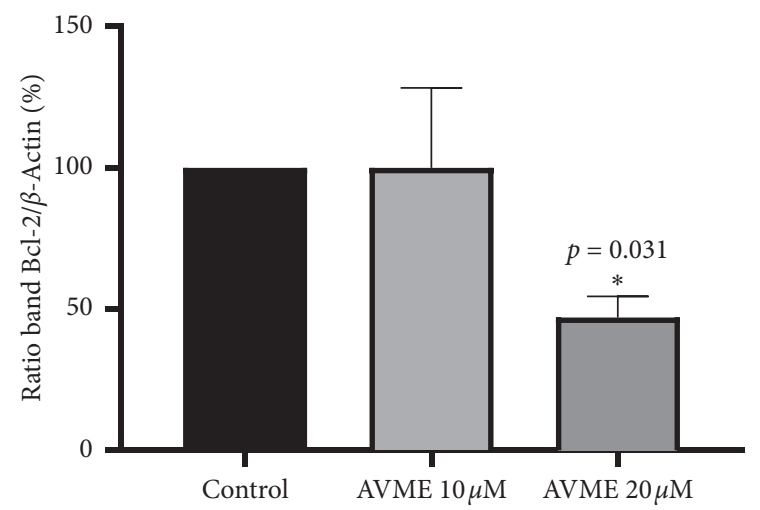

(c)

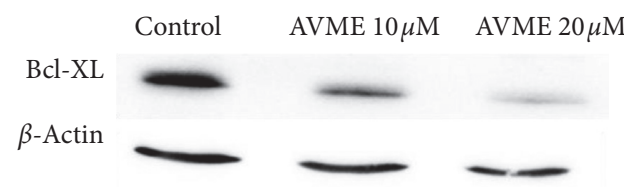

(b)

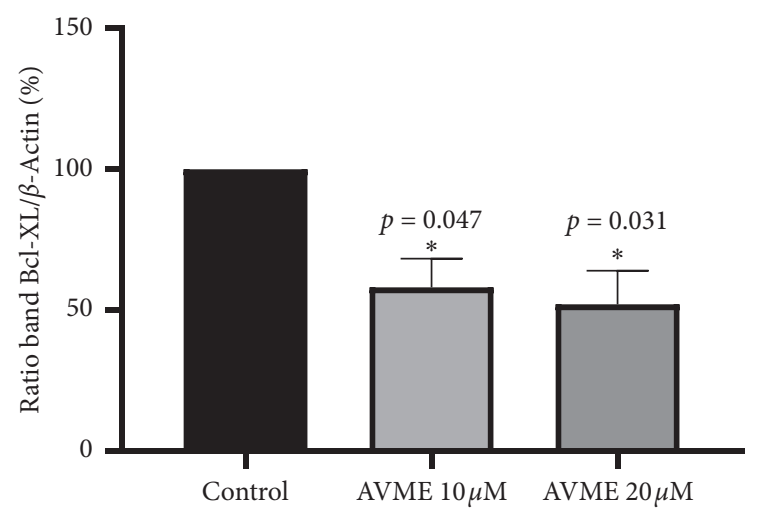

(d)

Figure 6: Effects of AVME on Western blot analysis of Bcl-2 (a, c) and Bcl-XL (b, d) protein contents in MDA-MB-231 cells treated with 10 and $20 \mu \mathrm{M}$ of AVME for $24 \mathrm{~h}$. For Western blotting, $\beta$-actin was used as an internal control. (c, d) Results are expressed as mean \pm SD of three independent experiments. ${ }^{* *} p<0.05$ as compared to control.
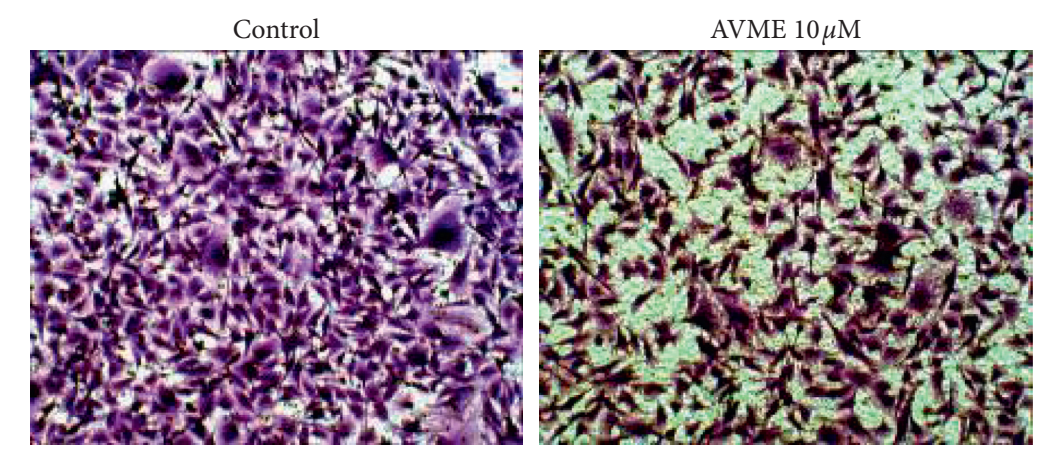

(a)

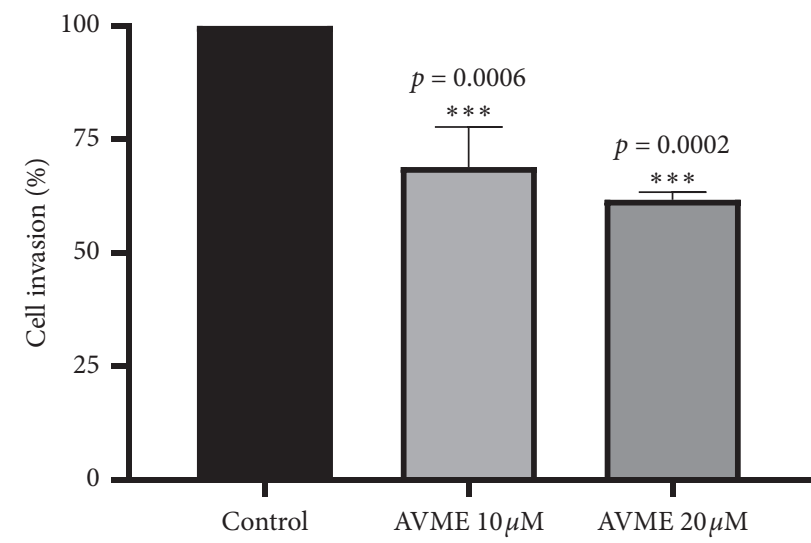

(b)

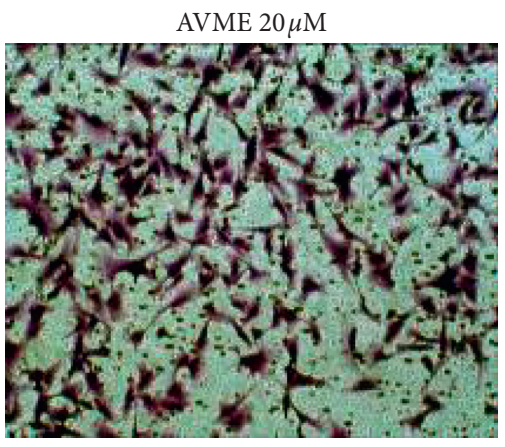




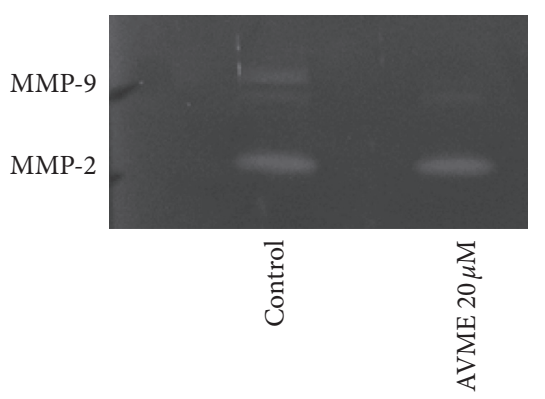

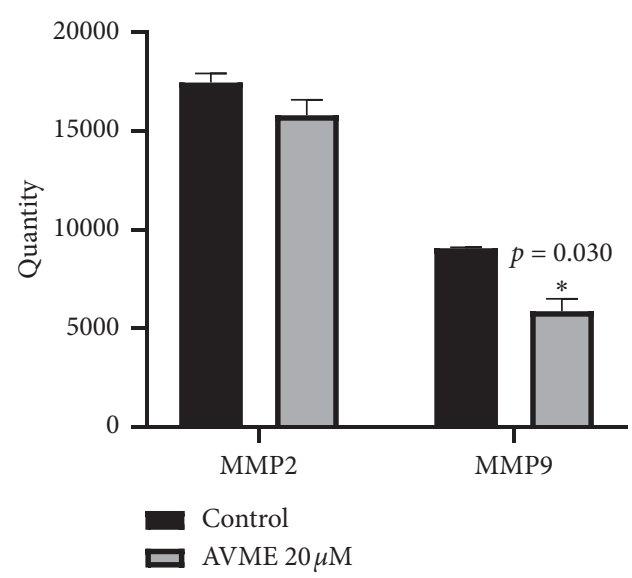

(b)

Figure 8: Effects of AVME on zymography assay of MMP-9 and MMP-2 (a) and graph of two independent assays (b) for metalloproteinase matrix activities in MDA-MB-231 cells treated with $20 \mu \mathrm{M}$ of AVME for $24 \mathrm{~h}$. The results are expressed as mean \pm SD of three independent experiments. ${ }^{*} p<0.05$ as compared to control.

death-inducing signaling complex is known to activate procaspase- 8 and caspase- 8 , constituting the extrinsic pathway of apoptosis [44].

ROS are the products of normal metabolic activities, which are kept fairly constant by regulating their production and elimination. ROS are essential to drive various regulatory pathways [45]. There is mounting evidence that ROS play a pivotal role in the induction of apoptosis via intrinsic mitochondrial cell death pathway or extrinsic death receptor pathway [46]. The ability of high concentrations of ROS to promote mitochondrial membrane pore formation and release apoptogenic molecules is being increasingly exploited by chemotherapeutic agents to induce apoptosis $[47,48]$. In this study, ROS levels were increased after incubation of MDA-MB231 cells with AVME. This result corroborates the findings of Brodská and Holoubek [49] who showed that a significant increase in apoptosis results from an increase in ROS. AVME exhibited a decrease in the transmembrane potential in MDA-MB-231 cells. This finding is in agreement with other studies, which also showed compounds inducing disturbances in mitochondrial membrane potential $[50,51]$. After incubation of MDA-MB231 cells with AVME, a concentration-dependent reduction in the expression of Bcl-XL and Bcl-2 was observed. The reduction in the $\mathrm{Bcl}-2$ proteins content indicates the intrinsic pathway-mediated induction of apoptosis by AVME. Flavonoids are well known proapoptotic compounds, which exert cytotoxicity by the generation of ROS, disruption of mitochondrial transmembrane potential, cytosolic release of cytochrome $c$, decrease in Bcl-2, and ultimate apoptosis [52].

Although $\mathrm{CC}_{50}$ values of AVME were $\sim 20 \mu \mathrm{M}$ for the breast cancer cells tested, they induced a slight increase of apoptosis cell population (7.9\%), suggesting that apoptosis plays a partial role in the AVME-induced cytotoxicity. This has encouraged authors to look for alternative mechanisms. The in vitro antitumor effect of
AVME was strengthened by the fact that it induced the arrest of MDA-MB-231 cells in G2/M and S phases. The ability to block the cell cycle in the G2/M phase has been exhibited by several phytochemicals with antiproliferative and cytotoxic effects [53]. An important observation of the present study is that AVME-mediated decreased cell migration and invasion. Cell migration is an important step for cancer progression and metastasis [54]. The levels of various proteinases, such as MMP-2 and MMP-9, are known to be increased during inflammatory diseases and in cancer [53]. These proteins are able to damage the extracellular matrix, altering the cell-cell and cell-extracellular matrix interaction in cancer and consequently inducing tumor promotion, invasion, and metastasis [53]. Mehner et al. [55] demonstrated that the MMP-9 knockdown in MDA-MB-231 cells was able to reduce cell invasion in Matrigel transwell assay by $90 \%$ while MMP-2 knockdown reduced cell invasion by approximately $50 \%$. Research indicated that MMP-9 is closely related to the invasion of MDA-MB 231 cells. Based on this information, we suggest that AVME may be inhibiting the invasion of MDA-MB-231 cells possibly by suppressing the MMP-9 activity. The precise mechanisms of action of AVME and target proteins (if any) have not yet been discovered, thus giving room for further investigation.

\section{Conclusions}

In summary, our study is the first demonstration of the fact that AVME, a prenylated flavanone isolated from the African medicinal plant E. droogmansiana, induces cytotoxic effect in breast cancer cell lines by triggering apoptosis via ROS-mediated mitochondrial pathway characterized by activation of caspase- 3 and caspase- 9 and downregulation of $\mathrm{Bcl}-2$ and Bcl-XL proteins. Moreover, AVME exhibits antiinvasion activities by the inhibition of MMP-9 activity. Nevertheless, further investigations are needed to comprehend the full potential of these results. 


\section{Abbreviations}

$\begin{array}{ll}\text { AVME: } & \text { Abyssinone V-4' methyl ether } \\ \text { AO: } & \text { Acridine orange } \\ \text { BSA: } & \text { Bovine serum albumin } \\ \text { CC }_{50}: & \text { Cytotoxic concentration which kills } 50 \% \text { of cells } \\ \text { DCFH- } & 2^{\prime}, 7^{\prime} \text {-Dichlorofluorescein diacetate } \\ \text { DA: } & \\ \text { DMBA: } & 7,12 \text {-Dimethylbenz(a)anthracene } \\ \text { DMEM: } & \text { Dulbecco's modified Eagle medium } \\ \text { EB: } & \text { Ethidium bromide } \\ \text { ER: } & \text { Estrogen receptor } \\ \text { IMC: } & \text { Intact membrane cells } \\ \text { PI: } & \text { Propidium iodide } \\ \text { PR: } & \text { Progesterone receptor } \\ \text { GPS: } & \text { Global positioning system } \\ \text { NHC: } & \text { National Herbarium of Cameroon } \\ \text { SEM: } & \text { Standard error of mean. }\end{array}$

\section{Data Availability}

The data and materials used in this study are available from the corresponding author upon request.

\section{Conflicts of Interest}

The authors declare no conflicts of interest.

\section{Authors' Contributions}

ZS, JC, TBCP, BA, and DN designed the experiments. AJGY and ET performed the phytochemical analysis. ZS, JC, and LVK performed the in vitro experiments. ZS, JC, and LVK analyzed the data. ZS wrote the first draft, and $\mathrm{AB}$ reviewed the manuscript with editing. All authors read and approved the final version of the manuscript.

\section{Acknowledgments}

This work was performed with the support from $\mathrm{CNPq}$, Brazilian National Council for Scientific and Technological Development and TWAS, The Academy of Sciences for the Developing World, to Prof. Dr. Stéphane Zingue (Grant no. 190741/2015-5). Dr Julia Cisilotto received a fellowship from CAPES, Coordination of Improvement of High Level Personnel (Brazil).

\section{Supplementary Materials}

Supplementary Figure 1: Dot plot (A) representative of one experiment of apoptosis measurement by Annexin-V-FITC/ PI staining MCF-7 cells. Cells were treated for $24 \mathrm{~h}$ with AVME at concentrations of 11,21 , and $42 \mu \mathrm{M}$. The graph (B) shows the percentage of cells in apoptosis or necrosis of 3 independent experiments. Supplementary Figure 2: Effect of AVME on cell cycle distribution in MCF-7 cells after $24 \mathrm{~h}$. Cells were treated for $24 \mathrm{~h}$ with 5,11 , and $21 \mu \mathrm{M}$ of AVME and stained with PI. Following flow cytometry, cellular DNA profile was analyzed using the software WinMDI 2.9. Data represent the percentage of cell counts in sub-G0/G1 (A),
G0/G1 (B), S (C), and G2/M (D) phases. Histograms (E) represent one experiment of cell cycle. The results are expressed as the percentage of cells in each cell cycle phase of three independent experiments. (Supplementary Materials)

\section{References}

[1] R. L. Siegel, K. D. Miller, and A. Jemal, "Cancer statistics, 2016,” CA: A Cancer Journal for Clinicians, vol. 66, no. 1, pp. 7-30, 2016.

[2] J. Ferlay, I. Soerjomataram, R. Dikshit et al., "Cancer incidence and mortality worldwide: sources, methods and major patterns in GLOBOCAN 2012," International Journal of Cancer, vol. 136, no. 5, pp. 359-386, 2015.

[3] International Agency for Research on Cancer, Globocan Cameroon Fact Sheets in: Breast Cancer, International Agency for Research on Cancer, Lyon, France, 2010.

[4] World Health Organization (WHO), Cancer. Cancer Profiles of Countries, WHO, Geneva, Switzerland, 2014.

[5] M. Plummer, C. De Martel, J. Vignat, J. Ferlay, F. Bray, and S. Franceschi, "Global burden of cancers attributable to infections in 2012: a synthetic analysis," Lancet Glob Health, vol. 4, no. 9, pp. 609-661, 2016.

[6] D. A. Vorobiof and R. Abratt, "The cancer burden in Africa," South African Medical Journal= Suid-Afrikaanse Tydskrif Vir Geneeskunde, vol. 97, no. 10, pp. 937-939, 2007.

[7] T. P. Kingham, O. I. Alatise, V. Vanderpuye et al., "Treatment of cancer in sub-Saharan Africa," Lancet Oncology, vol. 14, no. 4, pp. 158-167, 2013.

[8] Y. Wang, J. Wang, H. Wang, and W. Ye, "Novel taxane derivatives from Taxus wallichianawith high anticancer potency on tumor cells," Chemical Biology \& Drug Design, vol. 88, no. 4, pp. 556-561, 2016.

[9] A. L. Ososki and E. J. Kennelly, "Phyoestrogens: a review of present state of research," Phytotherapy Research, vol. 17, no. 8, pp. 17845-17869, 2003.

[10] H. Adlercreutz, W. Mazur, K. Stumpf et al., "Food containing phytoestrogens, and breast cancer," Biofactors, vol. 12, no. 1-4, pp. 89-93, 2000.

[11] W. M. Kone, K.-N. E. Solange, and M. Dosso, “Assessing subsaharian Erythrina for efficacy: traditional uses, biological activities and phytochemistry," Pakistan Journal of Biological Sciences, vol. 14, no. 10, pp. 560-571, 2011.

[12] S. K. Agrawal, M. Agrawal, P. R. Sharma, B. D. Gupta, S. Arora, and A. K. Saxena, "Induction of apoptosis in human promyelocytic leukemia HL60 cells by an extract From Erythrina suberosaStem bark," Nutrition and Cancer, vol. 63, no. 5, pp. 802-813, 2011.

[13] V. Kuete, L. P. Sandjo, D. E. Djeussi et al., "Cytotoxic flavonoids and isoflavonoids from Erythrina sigmoidea towards multi-factorial drug resistant cancer cells," Investigational New Drugs, vol. 32, no. 6, pp. 1053-1062, 2014.

[14] N. C. B. Nde, D. Njamen, S. T. Fomum et al., "In vitro estrogenic activity of two major compounds from the stem bark of Erythrina lysistemon (Fabaceae)," European Journal of Pharmacology, vol. 674, no. 2-3, pp. 87-94, 2012.

[15] M. A. Mvondo, D. Njamen, S. Tanee Fomum, and J. Wandji, "Effects of alpinumisoflavone and abyssinone V-4'-Methyl ether derived from Erythrina lysistemon (Fabaceae) on the genital tract of ovariectomized female wistar rat," Phytotherapy Research, vol. 26, no. 7, pp. 1029-1036, 2012.

[16] D. Njamen, S. Djiogue, S. Zingue, M. A. Mvondo, and B. N. Nkeh-Chungag, "In vivo and in vitro estrogenic activity of extracts from Erythrina poeppigiana (Fabaceae)," Journal of 
Complementary and Integrative Medicine, vol. 10, no. 1, pp. 63-73, 2013.

[17] S. Djiogue, M. Halabalaki, D. Njamen et al., "Erythroidine alkaloids: a novel class of phytoestrogens," Planta Medica, vol. 80 , no. 11 , pp. 861-869, 2014.

[18] A. Maiti, M. Cuendet, V. L. Croy, D. C. Endringer, J. M. Pezzuto, and M. Cushman, "Synthesis and biological evaluation of $( \pm)$-abyssinone II and its analogues as aromatase inhibitors for chemoprevention of breast cancer," Journal of Medicinal Chemistry, vol. 50, no. 12, pp. 2799-2806, 2007.

[19] G. V. Rao, B. N. Swamy, V. Chandregowda, and G. C. Reddy, "Synthesis of $( \pm)$ abyssinone I and related compounds: their anti-oxidant and cytotoxic activities," European Journal of Medicinal Chemistry, vol. 44, no. 5, pp. 2239-2245, 2009.

[20] S. D. Sokeng, E. Talla, V. Jeweldai et al., "Anti-inflammatory effect of abyssinone V-4'-methyl ether on acute and chronic inflammation models," Hygeia. Journal of Drug and Medicine, vol. 5, pp. 5117-5124, 2013.

[21] E. Talla, S. Ngatcha, J. Njapdounke et al., “Anti-convulsivant and sedative like-effect of abyssinone V-4' methyl ether isolated from Erythrina droogmansiana (Leguminosae)," Journal of Applied Pharmaceutical Science, vol. 5, pp. 1-5, 2015.

[22] D. Njamen, M. A. Mvondo, T. Nanbo Gueyo, S. Zingue, S. Tanee Fomum, and J. Wandji, "Erythrina lysistemon-derived flavonoids account only in part for the plant's specific effects on rat uterus and vagina," Journal of Basic Clinical Physiol Pharmacol, vol. 26, pp. 287-294, 2015.

[23] A. B. Tueche, S. Zingue, E. N. Tchoupang et al., "Abyssinone V-4' methyl ether isolated from Erythrina droogmansiana (Leguminosae) inhibits cell growth and mammary glands hyperplasia induced in Swiss mice by the 7, 12 dimethylbenz(a) anthracene," Evidence-Based Complementary and Alternative Medicine, vol. 2018, Article ID 7959068, 10 pages, 2018.

[24] A. Yenesew, J. O. Midiwo, M. Miessner, M. Heydenreich, and M. G. Peter, "Two prenylated flavanones from stem bark of Erythrina burttii," Phytochemistry, vol. 48, no. 8, pp. 14391443, 1998.

[25] J. O’Brien, I. Wilson, T. Orton, and F. Pognan, "Investigation of the alamar blue (resazurin) fluorescent dye for the assessment of mammalian cell cytotoxicity," European Journal of Biochemistry, vol. 267, no. 17, pp. 5421-5426, 2000.

[26] E. Robles-Escajeda, D. Lerma, A. M. Nyakeriga et al., "Searching in mother nature for anti-cancer activity: antiproliferative and pro-apoptotic effect elicited by green barley on leukemia/lymphoma cells," PLoS One, vol. 8, no. 9, Article ID e73508, 2013.

[27] O. H. Lowry, N. J. Rosebrough, A. L. Farr, and R. J. Randall, "Protein measure with the folin phenol reagent," Journal of Biological Chemistry, vol. 193, pp. 265-275, 1951.

[28] J. Cisilotto, L. P. Sandjo, L. G. Faqueti et al., "Cytotoxicity mechanisms in melanoma cells and UPLC-QTOF/MS2 chemical characterization of two Brazilian stingless bee propolis: uncommon presence of piperidinic alkaloids," Journal of Pharmaceutical and Biomedical Analysis, vol. 149, pp. 502-511, 2018.

[29] M. Rafieian-Kopaei and M. Movahedi, "Breast cancer chemopreventive and chemotherapeutic effects of Camellia sinensis (green tea): an updated review," Electronic Physician, vol. 9, no. 2, pp. 3838-3844, 2017.

[30] D. Bathia, A. Mandals, E. Nevo, and A. Bishayee, "Apoptosisinducing effects of extracts from desert plants in HepG2 human hepatocarcinoma cells," Asian Pacific Journal of Tropical Biomedicine, vol. 5, no. 2, pp. 87-92, 2015.
[31] E. Harlev, E. Nevo, E. Lansky, R. Ofir, and A. Bishayee, "Anticancer potential of aloes: antioxidant, antiproliferative, and immunostimulatory attributes," Planta Medica, vol. 78, no. 09, pp. 843-852, 2012.

[32] S. Zingue, A. N. Njuh, A. B. Tueche et al., "In vitro cytotoxicity and in vivo anti-mammary tumor effects of the hydroethanolic extract of Acacia seyal (Mimosaceae) stem bark," BioMed Research International, vol. 2018, Article ID 2024602 , 13 pages, 2018.

[33] S. Zingue, J. Cisilotto, A. B. Tueche et al., "Crateva adansonii DC, an African ethnomedicinal plant, exerts cytotoxicity in vitro and prevents experimental mammary tumorigenesis in vivo," Journal of Ethnopharmacology, vol. 190, pp. 183-199, 2016.

[34] L. T. Riss, A. R. Moravec, L. A. Niles et al., Cell Viability Essays, Essay guideline Manual, 2013.

[35] P. Giovannelli, M. Di Donato, G. Galasso, E. Di Zazzo, A. Bilancio, and A. Migliaccio, "The androgen receptor in breast cancer," Frontiers in Endocrinology, vol. 9, p. 492, 2018.

[36] A. Monks, D. Scudiero, P. Skehan et al., "Feasibility of a highflux anticancer drug screen using a diverse panel of cultured human tumor cell lines," JNCI Journal of the National Cancer Institute, vol. 83, no. 11, pp. 757-766, 1991.

[37] S. El-Masry, M. E. Amer, M. S. Abdel-Kader, and H. H. Zaatout, "Prenylated flavonoids of Erythrina lysistemon grown in Egypt," Phytochemistry, vol. 60, no. 8, pp. 783-787, 2002.

[38] D. Hanahan and A. R. Weinberg, "Hallmarks of cancer: the next generation," Cell, vol. 144, pp. 647-674, 2011.

[39] U. Ziegler and P. Groscurth, "Morphological features of cell death," Physiology, vol. 19, no. 3, pp. 124-128, 2004.

[40] M. Jensen, A. Engert, F. Weissinger et al., "Phase I study of a novel pro-apoptotic drug R-etodolac in patients with B-cell chronic lymphocytic leukemia," Investigational New Drugs, vol. 26, no. 2, pp. 139-149, 2008.

[41] V. Kumar, AK. Abbas, N. Fausto, JC. Aster, and R. Cotran, Pathologic Basis of Diseasepp. 25-32, Elsevier, Philadelphia, Saunders, 8 edition, 2010.

[42] J. C. Reed, "Bcl-2 family proteins: regulators of apoptosis and chemoresistance in haematologic malignancies," Semin Haematol, vol. 34, pp. 9-19, 1997.

[43] G. Kroemer, W. S. El-Deiry, P. Golstein et al., "Classification of cell death: recommendations of the nomenclature committee on cell death," Cell Death \& Differentiation, vol. 12, no. S2, pp. 1463-1467, 2005.

[44] M. A. O’Brien and R. Kirby, “Apoptosis: a review of proapoptotic and antiapoptotic pathways and dysregulation in disease," Journal of Veterinary Emergency and Critical Care, vol. 18 , no. 6, pp. 572-585, 2008.

[45] B. C. Dickinson and C. J. Chang, "Chemistry and biology of reactive oxygen species in signaling or stress responses," Nature Chemical Biology, vol. 7, no. 8, pp. 504-511, 2011.

[46] K. Sinha, J. Das, P. B. Pal, and P. C. Sil, "Oxidative stress: the mitochondria-dependent and mitochondria-independent pathways of apoptosis," Archives of Toxicology, vol. 87, no. 7, pp. 1157-1180, 2013.

[47] M. F. Renschler, "The emerging role of reactive oxygen species in cancer therapy," European Journal of Cancer, vol. 40, no. 13, pp. 1934-1940, 2006.

[48] D. O. Moon, M. O. Kim, J. D. Lee, Y. H. Choi, and G. Y. Kim, "Rosmarinic acid sensitizes cell death through suppression of TNF- $\alpha$-induced NF- $\kappa$ B activation and ROS generation in human leukemia U937 cells," Cancer Letters, vol. 288, no. 2, pp. 183-191, 2009. 
[49] B. Brodská and A. Holoubek, "Generation of reactive oxygen species during apoptosis induced by DNA-damaging agents and/or histone deacetylase inhibitors," Oxidative Medicine and Cellular Longevity, vol. 2011, pp. 1-7, 2011.

[50] S.-Y. Jeong and D.-W. Seol, "The role of mitochondria in apoptosis," BMB Reports, vol. 41, no. 1, pp. 11-22, 2008.

[51] K. Silihe, S. Zingue, E. Winter et al., "Ficus umbellata vahl. (Moraceae) stem bark extracts exert antitumor activities in vitro and in vivo," International Journal of Molecular Sciences, vol. 18, no. 6, p. 1073, 2017.

[52] S. Shukla and S. Gupta, "Apigenin-induced prostate cancer cell death is initiated by reactive oxygen species and p53 activation," Free Radical Biology and Medicine, vol. 44, no. 10, pp. 1833-1845, 2008.

[53] J. M. Visanji, D. G. Thompson, and P. J. Padfield, "Induction of G2/M phase cell cycle arrest by carnosol and carnosic acid is associated with alteration of cyclin A and cyclin B1 levels," Cancer Letters, vol. 237, no. 1, pp. 130-136, 2006.

[54] F. Entschladen, T. L. Drell, K. Lang, J. Joseph, and K. S. Zaenker, "Tumour-cell migration, invasion, and metastasis: navigation by neurotransmitters," The Lancet Oncology, vol. 5, no. 4, pp. 254-258, 2004.

[55] C. Mehner, A. Hockla, E. Miller, S. Ran, D. C. Radisky, and E. S. Radisky, "Tumor cell-produced matrix metalloproteinase 9 (MMP-9) drives malignant progression and metastasis of basal-like triple negative breast cancer," Oncotarget, vol. 5, no. 9, pp. 2736-2749, 2014. 